\title{
TEACHERS' TECHNIQUES AND PROBLEMS IN TEACHING READING
}

\author{
${ }^{1)}$ Yanuarti Apsari, ${ }^{2)}$ Yana \\ ${ }^{1,2)}$ Program Studi Pendidikan Bahasa Inggris, STKIP Siliwangi
}

\begin{abstract}
This study is aimed at exploring teachers' techniques in teaching reading comprehension at one senior high school in Bandung Barat and investigating exploring the problems that the teachers encountered in teaching reading. This study employed a case study research design which used two data collection, observation and questionnaire. Two English teachers were purposively selected to participate in this research. Then, they were analyzed and reported descriptively. After being analyzed, the data revealed that the respondents used the teaching reading comprehension techniques in three reading stages: prereading, while-reading, and post-reading stages. In pre-reading stage, they applied Previewing technique and Vocabulary Instruction Technique; Pre-Reading Questions and Brainstorming Technique and discussing text type. Then, in while reading stage, they used Question-Answering Techniques, Vocabulary Instruction Technique, Recitation and Reading aloud. In post-reading stage, they conducted reviewing technique and follow up strategy. The data also indicated that in teaching reading comprehension, there were four problems encountered by the respondents in teaching reading: lack of students' vocabulary mastery, lack of motivation in reading, students were not used to read a lot on a regular basis and teaching time allocation. With reference to the findings, it is recommended for English teacher to select appropriate technique in teaching reading which is relevant to the students' needs. In addition, the teachers also are expected to improve their ability in teaching practice. It can be done through joining some trainings and workshops about techniques in teaching, reading a lot of sources, and sharing information with others teachers.
\end{abstract}

Key Words: Teacher's Techniques, Reading Comprehension and Problem.

\begin{abstract}
ABSTRAK
Penelitian ini bertujuan untuk mengeksplorasi teknik guru dalam membaca pemahaman mengajar di salah satu SMA di Bandung Barat dan menyelidiki menjelajahi masalah yang dihadapi guru dalam membaca mengajar. Penelitian ini menggunakan desain penelitian studi kasus yang menggunakan dua pengumpulan data, observasi dan kuesioner. Dua guru bahasa Inggris secara sengaja dipilih untuk berpartisipasi dalam penelitian ini. Kemudian, mereka dianalisis dan dilaporkan secara deskriptif. Setelah dianalisis, data menunjukkan bahwa responden menggunakan teknik membaca pemahaman ajaran dalam tiga tahap membaca: pra-membaca, sementara-membaca, dan tahap pasca-membaca. Pada tahap pra-membaca, mereka menerapkan teknik dan Teknik Kosakata Instruksi Meninjau; Pre-Reading Pertanyaan dan Brainstorming Teknik dan mendiskusikan jenis teks. Kemudian, di saat membaca panggung, mereka menggunakan Pertanyaan-Menjawab Teknik, Kosakata Instruksi Teknik, Zikir dan Membaca dengan suara keras. Pada tahap pasca-membaca, mereka yang dilakukan meninjau teknik dan menindaklanjuti strategi. Data ini juga menunjukkan bahwa dalam membaca pemahaman ajaran, ada empat masalah yang dihadapi oleh responden dalam membaca ajaran: kurangnya penguasaan kosakata siswa, kurangnya motivasi dalam membaca, siswa tidak digunakan untuk banyak membaca secara dan pengajaran waktu yang teratur alokasi. Dengan mengacu pada temuan, disarankan untuk guru bahasa Inggris untuk memilih teknik yang tepat dalam membaca mengajar yang relevan dengan kebutuhan siswa. Selain itu, guru juga diharapkan dapat meningkatkan kemampuan mereka dalam praktek mengajar. Hal ini dapat dilakukan melalui beberapa bergabung pelatihan dan lokakarya tentang teknik dalam mengajar, membaca banyak sumber, dan berbagi informasi dengan guru lain.
\end{abstract}

Kata Kunci: Teknik Guru, Pemahaman Membaca dan Masalah. 


\section{A. INTRODUCTION}

In Indonesia, since 2006 a decentralized school level curriculum (School Based Curriculum), which is well-known as Kurikulum Tingkat SatuanPendidikan (KTSP) was implemented in the attempt to improve the quality of national education output. The establishment of School Based Curriculum was based on law No.20, 2003 about National Education System and Government Regulation no. 19, 2005 about national Education Standard. It is arranged by the units of education based on the Content Standard (Standar Isi) and Graduate Competence Standard (StandarKompetensiLulusan) which is in line with guidelines from BNSP. In other words, BNSP develops Content Standard and Graduate Competence Standard which includes basis framework and curriculum structure as the principle in developing the curriculum.

According to the Content Standard, the ultimate goal of learning English is to make the students to be able to participate in discourse or to communicate idea, feelings, etc. in spoken and written English accurately, fluently, and in acceptable manners. In addition, according to the Permendiknas No.23, 2006 on the Graduate Competence standard for primary and secondary schools (Depdiknas, 2006), the teaching of English includes the four language skills: listening, speaking, reading and writing. Listening and reading are considered to be receptive skills, whereas speaking and writing are considered to be productive skills. The aim of the teaching of the receptive skills is to understand meaning conveyed in different text types (recount, narrative, procedure, descriptive, news item, spoof, report, analytical exposition, hortatory exposition, discussion and review texts), while the teaching of productive skills aims at teaching students to express meaning in these text types. Therefore, it can be concluded that reading is considered as one of the most important skills that students need to acquire(Levine et al. 2000: 1 in Nashriyah, 2010: 84).

However, since English in Indonesia is a foreign language, most students at any level of education get difficulty in reading English text. Many research results (Hamra, 1993 and 1996; Mardiana, 1993; Kweldju 2001 cited in Syatriana, 2010) indicated that the ability of Indonesian students to read English texts was very low. Most students are not able to read English with complete comprehension. Thus, the Indonesian students need help in reading comprehension. Considering the fact above, the researcher decided to conduct the research that focuses on the teachers' techniques and teachers' problem in teaching reading.

In line with the purposes of the study above, this study attempted to address the following questions:

1. What techniques do the teachers apply in teaching reading?

2. What problems do the teachers encounter in teaching reading?

Regarding the problem stated above, this study aims to investigate teachers' techniques in teaching reading comprehension and the problems faced by the teachers in teaching reading. Regarding the problem stated above, this study aims to investigate the techniques that the teachers apply in teaching reading and the problems encountered by the teachers in teaching reading.

The result of this study would expectedly be beneficial for teachers, students and other researchers. For teachers, the result of this study would give valuable input for the practice of teaching reading in senior high school. For students, the result of this study would be valuable to make the students to be motivated and interested in reading so that they can easily comprehend a variety of English texts. It hopes that this study will help other researchers to do the some related researches in deeper, further and better techniques.

The aim of giving definition of key terms is to avoid the misunderstanding that may exist in investigating this study. The terms, which are needed to be defined, are as follows:

a. Reading is to process text meaning through some process of interaction with print (Alderson, 2000: 1).

b. Problems refer to the difficulties faced by the English teachers in teaching English reading texts in senior high school..

c. Perception refers to the ways the students perceive reading experiences during class activity.

\section{B. LITERATURE REVIEW AND METHODOLOGY}




\section{Literature Review}

The chapter covers some theories underlying the present study. The first broad theory is to do with reading. The second theory deals with stages of reading. This chapter also explains reading process, reading comprehension and techniques in teaching reading

\section{a. Reading}

Reading is to process text meaning through some process of interaction with print (Alderson, 2000: 1).In academic context, reading is considered as one of the most important skills that university students of English as a Second Language need to acquire (Levine et al. 2000: 1 in Nashriyah, 2010: 84). Reading is not only important in developing language intuition and determining academic success but also it is important for completing certain task. Accordingly, it is obligatory for students especially those who study in colleges to have good reading skills. They should acquire the ability so that they can easily handle any references they need for accomplishing every task given to them.

Reading is essentially divided into two components: word recognition and comprehension.Haris and Sipay (1980: 366) say that word recognition means that the reader can determine the oral equivalent of a written or printed word. In other words, the readers are able to identify the word if they are able to understand the intended meaning of a word. Meanwhile, ccomprehensionrefers toa constructive process in which student creates meaning based on their background knowledge (Gunning, 2010: 1). It indicates that comprehending a text is considered as an interactive process between the reader's background knowledge and the text (Carrell \& Eisterhold, 1988:76-77). Readers' knowledge and experiences of the world around them also influence how a text is read or processed, as what Berardo defines as schema theory (1932 cited in Berardo, 2006). Consequently, both word recognition and comprehension skills are necessary for readers who are encountering content area texts (Lapp \& Flood, 1986, in Syatriana, 2010).

In line to the explanation above, Nuttal (1996) states that that there are three central ideas behind reading: the idea of meaning, the transfer of meaning from one to another, and the transfer of message from the writers to the readers.

\section{b. Reading Process}

Chastain (1998) cited in Razi (2001) defines reading process as an active cognitive system operating on printed material in the attempt to comprehend the text. The readers process texts in three ways: bottom-up, top-down, and interactive processing (McNeil, 1992).

\section{c. Bottom-up Processing}

In bottom-up processing readers must first recognize a multiplicity of linguistic signals (letters, morphemes, syllables, words, phrases, grammatical cues, and discourse markers) and use their linguistic data processing mechanism to impose some sort of order on the linguistic signals (Goodmanas cited in Brown, 2001: 298-299). It means that the readers construct the meaning by reading word for word, letter for letter, carefully analyzing both vocabulary and syntax. This is often related to poor or slow readers, but can sometimes occur when the readers own schema knowledge is inadequate. Therefore, this model weakens the significance of reading comprehension because the focus is on the understanding of linguistic knowledge but little attention is paid to schema, i.e. related cultural background, the whole text, etc.

\section{d. Top-down Processing}

Top-Down is a processing in which the readers use their own intelligence and experience to understand the text (Goodman, as cited in Brown, 2001: 298-299). They construct the meaning through the clues in the text and their good schema knowledge. This is often related to a good reader, who does not read word for word but see through the text in order to be able to guess the meaning of the words or phrases.

\section{e. Interactive Processing}

The most comprehensive description of the reading process is interactive model, which suggests that "every component in the reading process can interact with any other component" (Alderson, 2000), combining elements both bottom-up and top-down models. Readers may employ bottom-up process as a base for comprehending a text and then turn to top-down process to complete highlevel interpretation of the content of the text. Thus, in the perspective of the interactive model, the top- 
down approach is used to predict the meaning and the bottom-up approach is to check it.

On the basis of what just previously explained, it is clear that the goal of reading is not to remember every word in the text, but to comprehend the text generally (Grabe and Stoller, 1990: 12). As Durkin (1993) claimed that reading comprehension skill has come to be the "essence of reading".

\section{f. Reading Comprehension}

Lems and Soro (2010: 170) state that reading comprehension is the ability to construct meaning from a given written text. It is viewed as a dynamic process in which the reader "constructs" meaning based on information that a reader gathers from a text. Furthermore, Sweet and Snow (2003: 1) define that reading comprehension is the process of simultaneously extracting and constructing meaning. In other words, readers recognize both challenges: figuring out how print represents words and engaging in the translation of print to sound accurately and efficiently (extracting), and at the same time formulating a representation of the information being presented, which inevitably requires building new meanings and integrating new with old information (constructing meaning). Therefore, comprehension depends on integrating new knowledge with a network of prior knowledge (Harris and Hodges, 1995: 227).

Zamel (1982) contends that meaning construction can be facilitated by incorporating and emphasizing activities that require the ESL readers to engage in, to interact with, and synthesize the information from course texts. It indicates that meaning construction is crucial to text comprehension, and both appear to depend upon the degree of active reader response to text (Leki, 1993). From the above description, it is obvious that reading comprehension is a process of constructing a meaning from a written text that involves the interaction of the reader's prior knowledge with the new given information.

According to Ahuja (2001 in Mohammad, 1999: 27), there are three levels of comprehension. The first level is literal comprehension. Comprehension of this level involves surface meanings. At this level, can ask the students to find information and ideas that are explicitly stated in the text. The second level is interpretive or referential comprehension. At this level students go beyond what is said and read for deeper meanings. They must be able to read critically and analyze carefully what they have read. This level includes thinking process such as drawing conclusions, making generalizations and predicting outcomes. Finally, the third level of comprehension is critical reading whereby ideas and information are evaluated. At this level, the teacher can test students' ability to differentiate between fact and opinion, the ability to recognize persuasive statements, and the ability to judge the accuracy of the information given in the text.

\section{g. Reading Strategies}

According to Amanda (2007: 22), reading strategies are techniques and methods that readers use to make their reading successful. They are regarded as one of the fundamental factors since they can promote students' comprehension in reading. There are reasons that make strategies in reading important. First, readers can solve any reading problem by using the appropriate strategy. Second, strategies help readers to learn how to understand the text. Finally, strategies help readers realize how they are thinking so that they can think more deeply and more consciously.

Brown (2001: 306-311) suggests the following reading strategies for those learning a second language:

1) Identify the purpose in reading.

2) Use graphemic rules and patterns to aid in bottom-up decoding.

3) Use efficient silent reading techniques for relatively rapid comprehension (for intermediate and advanced levels).

4) Skim the text for main ideas.

5) Scan the text for specific information.

6) Use semantic mapping or clustering.

7) Guess when you are not certain.

8) Analyze vocabulary.

9) Distinguish between literal and implied meanings.

10) Capitalize on discourse markers to process relationships.

The current explosion of research in second language reading has begun to focus on readers' strategies. Reading strategies are of interest for what they reveal about the way readers manage their interaction with written text and how these strategies are related to text comprehension. A study conducted by Tercanlioglu (2004) who found that the use of various reading strategies improved the students' reading comprehension. 
The other strategy in teaching English is extensive reading. Gebhard (1999: 208) says that the goal of extensive reading is to improve reading skills by processing a quantity of materials that can be comprehended and pleasurable. Green and Oxford (cited in Brown, 2001: 301) add that reading for pleasure and reading without looking up all the unknown words were both highly correlated with overall language proficiency. Therefore, reading extensively is helpful to comprehend the text.

Extensive reading is used to obtain a general understanding of a subject and includes reading longer texts for pleasure. It focuses on the meaning of the text itself not the language. It can be done by giving the students a chance to choose what they want to read. It is stated that they are much more likely to read with enthusiasm if they have made the decision about what they read (Gebhard, 1999).

On the contrary, intensive reading occurs when the learner is focused on the language rather than the text. It involves learning new vocabulary, studying the grammar and expression in the text, translating the passage or other tasks that involve the students in looking intensively (inside) the text. In other words, students need to read carefully to understand the meaning of the text accurately. In teaching reading, it is recommended that extensive reading should be integrated with intensive reading. In line with this, Brown (2001: 301) suggests that the teacher should give strong consideration to the teaching of extensive reading without abandoning intensive reading.

\section{h. Reading Activities}

According to Nuttall (1996: 31), the aim of reading program, i.e "to enable students to read, without help, unfamiliar authentic texts, at appropriate speed, silently and with adequate understanding". It means that developing reading activities involves more than identifying a text that is "at the right level," writing a set of comprehension questions for students to answer after reading, handing out the assignment and sending students away to do it. Consequently, a reading lesson, in which we intend to grasp meaning of new information based on what we already know, think or feel about the topic we are about to read should be divided into three stages based on the purposes of each stage, ie. The pre-, whilst- and post reading stage (Wallace, 1992).

\section{1) Pre-Reading Stage}

A reading lesson should begin with a pre-reading activity to introduce the topic and to make sure students have enough vocabulary, grammar, and background information to understand the text. This activity is regarded as the guidance before reading. Guidance before reading may involve providing a reason for reading, introduction of the text, breaking up the text, dealing with unfamiliar language, and asking leading questions (Nuttall, 1996: 152).

In pre-reading stage, there are three important steps that need to be applied by the teacher, namely: establishung the purpose of the reading (Wallace, 1992), activating and building background knowledge (Cook, 1991, Wallace, 1992, Closs, 2006).Generating text type or text structure is another activity that can be done in this stage (Wallace, 1992).Gillet as cited in in Mulyani and Siswayani (2006) states that the way you read will depend on your purpose. It means that recognizing the purpose for reading will help students to select appropriate reading strategies. Thus, the teacher should provide the students the purpose of reading in order to help the students comprehend the text.

According to Barnet (1988), one of the activities in pre-reading stage is text types discussions. This strategy is very useful for students as an aid to comprehend the text since reader understanding of how the texts are organized influences reading comprehension (Anderson, 1990). As stated by Wallace (1992) that discussing the text type in teaching reading is intended to familiarize students with the text structure and to show how these language features can help them to work out the main function of the text.

The common activities in the pre-reading stage are introduction of a text is useful for students who have a little background knowledge about the topic. In this stage, the teacher usually works on general aspects of the topic to elicit what students already know about the topic and make them ready for the new information. It can make them comfortable to read the text. Breaking up a text is needed only when the text is too long. Leading questions guides the students to comprehend the text, so these questions should not ask for detailed answers. And dealing with unfamiliar language involves discussing unfamiliar grammar and vocabulary. According to Gipe (1979 cited in 
Mickulecky, 1990), this activity is very useful to help the students to memorize the words paired with a short definition or a synonym. Furthermore, Closs (2006) adds that providing new vocabulary words can avoid the situation in which the students will spend too much time figuring out the new words that will be unable to comprehend the entire reading text.

Based on the description above, it can be concluded thatpre reading stage has the purpose which refers to put students to activate their prior and background knowledge to focus their attention on what they are going to learn.

\section{2) While Reading Stage}

The aim of while reading stage is to help students understand writer's purpose and text structure to clarify the content of the text (Wallace, 1992). This stage focuses on the developments of the students' reading skills, train students in applying reading strategies and improves their control of English.

There are two reading common reading techniques which are mostly used during while-reading stage namely questioning technique and vocabulary technique (Wallace, 1992; Li-Juan, 2007). The stage will be dominated with discussions and activities that match students' interest in order to help the teacher gear the activities toward achieving the purpose. Some reading activities that learners can do are making a presentation, discussing the author's ideas, reading aloud, learning grammar, finding the meaning, finding the main idea, summarizing, retelling, completing the picture, answering questions.

According to the result of the previous study conducted by Mulyani and Siswayani (2006) that students mostly like to share the information by answering the questions or retelling it in form of speaking or completing pictures and they do not like to learn grammar or vocabulary in context and guess the new words from the context.

\section{3) Post Reading Stage}

In this stage the students reflect what have been learned and the teacher asks questions to check the students' comprehension in reading. The types of the questions as proposed by Wallace (2001) are recalling, analyzing, comparing, inferencing and evaluating. In addition, Edmundson (2006) suggests the teacher needs to ask the students to do the summarizing activity.

After reading the text, the students are expected to have obtained new information from the text. At this stage, the students should be able to assess their own comprehension of the text and extend and elaborate on ideas from the text. They may be asked to agree or disagree with the authors or the characters in the text, relate the content to their own experience, connect the content with other works in the same field, discuss characters/incidents/ideas/feelings, and predict what can happen afterwards.In short, post reading stage is aimed at reinforcing students' awareness of other ways in which the topic could have been written. Another activity in this stage is followupactivity.It is the effective strategy to transfer reading skill to the texts and to integrate reading skill to other language skill (Wallace, 1992; Barnet 1988).

The importance of post reading activities cannot be denied, for at least three reading principles mentioned by Harmer (2007: 101-102) which can be found in post-reading activities, namely: students need to be engaged with what they are reading, students should be encouraged to respond to the content of the text, and student should be exploited to the reading texts to the full.

Common post reading activities are: identifying the author's purpose, creating stories or end of stories, reconstructing texts, and questioning texts. Post reading activities are expected to encourage students to reflect upon what they have read. Therefore, it can be implied that the main goal of the post-reading stage is to further develop and clarify interpretations of the text, and to help students remember what they have individually created in their minds from the text.

\section{4) Techniques in Teaching Reading}

Technique refers to any of wide variety of exercises, activities, devices used in language classroom for achieving the objective of the lesson (Brown, 2001).According to Glendinning and Holmstrom (1992), there are several techniques in teaching reading and the teacher needs to select the appropriate techniques based on the natural process of reading. 


\section{a) Establishing the Purpose of Reading (Wallace, 1992).}

Specific purpose for reading is one that helps guides students' efforts to focus on important information in the text. This specific focus should be explicitly stated before students begin reading. Moreover, Gillet as cited in in Mulyani and Siswayani (2006) states that the way you read will depend on your purpose. It means that recognizing the purpose for reading will help students to select appropriate reading strategies. Thus, the teacher should provide the students the purpose of reading in order to help the students comprehend the text.

\section{b) Activating and Building Background Knowledge (Cook, 1991, Wallace, 1992; Closs, 2006).}

Wallace (1992) suggests that in order to make sure that students can comprehend the text properly and quickly, a reading teachers need to know the reading material well to make clear what background knowledge the students may lack and give an introduction before the students begin to read it.

To activate students' background knowledge can be done by reviewing students' prior knowledge about the text such as by discussing what students know about the text, categorizing the information they already know, making prediction toward the text; and generating students' own questions (Cook, 1991). Therefore, the effective techniques to activate background knowledge include: brainstorming,pre-reading questioning, predicting and topic talking.

According to Crawford et al (2005: 29), brainstorming is a method for creating many ideas about a topic. This activity consists of inviting students to call out words, knowledge and experience that relevant to the text, relevant language and an expectation meaning (Hood et al, 2005, Wallace, 1992).

\section{c) Previewing the Text}

The techniques which can be used in this part are scanning and skimming. Skimming is the process of rapid glancing through a text either to search for a specific piece of information (a name, a date) or to get an initial impression of whether the text is suitable for a given purpose (Nuttall, 1996: 49). While, scanning is a skill that requires reading quickly through a text to look for specific information. Edmonson (2006) recommends that the teacher needs to provide some previewing questions that can help students focus their prereading activity and also activate students' prior knowledge.Previewing text is a beneficial preparation activity which enables students to establish their own expectations about what information they will find in the text and the way that information will be organized (Wallace, 2001).

\section{d) Questioning Technique and Vocabulary Technique.}

Question-answering technique is to answer the comprehension question. Anderson (1999) stated that justifying comprehension is a technique that ask the students to read a passage, then ask comprehension question, and then ask the class to justify the answer.

According to Wallace (2001), the questions should address three level of understanding: the explicit, implicit and the applied questions.Explicit questions refer to the questions which involve students to find the information available in the text, while implicit questions refer to the questions to recognize and summary the information based on their understanding though it is not stated in the text, and applied questions are required students to connect the text with their real life issue.

Explicit vocabulary instruction can be given through providing word definitions, synonym pairs, word lists, word associations, the keyword method, semantic mapping and semantic feature analysis.Marzban (2013) found that explicit instruction of vocabulary better influenced vocabulary learning among Iranian preintermediate learners.

\section{e) SQ3R (Survey, Question, Read, Recite, Review) Technique}

Survey: Students make predictions about the main idea and content by using their background knowledge of the topic.

Question: The students need to have questions in their mind in order to guide them to comprehend the text better. It can be their purpose in reading.Read: The students read the text to answer the purpose of questions that have been formulated. 
Recite: Students try to answer questions from memory or without looking at the text. It can be done through oral or written language.CAL (2008) argues that the recitation is effective because it enables the students to recall the important points from the text.

Review: The students try to reflect what they have read. They need to re-read several times to check their comprehension on particular information from the text. As stated by CAL (2006) that through reviewing activity, the teacher can also see how the information fits together in the students' understanding.

SQ3R also can be applied in three stages in reading activity (pre-reading, while-reading and post reading). To clarify the explanation, the diagram is presented as follow:

The SQ3R is a useful strategy for extracting the maximum amount of benefit from one's reading time. It helps readers to organize the structure of a subject in their mind. It also helps them to set study goals and to separate important information from irrelevant data. Eventually, the use of SQ3R strategy can significantly improve the quality of study time.

\section{5) The Problems in Teaching Reading}

Wallace (1992), Surong (2002) and Li-Juan (2007) mentions that there are three common problems that usually encountered by the teacher in teachingreading.

1. Vocabulary oriented teaching (Surong, 2002) and Li-Juan, 2007). In this case, the teachers' presentation mainly focus on the vocabulary. As a result, the teachers have no idea about the complexity of reading process.

2. The teachers seldom get down to learn their students needs, have the analyzed and tailor the teaching metthod accordingly (Li-Juan, 2007). Here, the teachers just rigidly follow the natural arrangement of texts and exercises with the help of their perceptual experiences. Then, they exploit the text just for its own sake, not to use it as a tool to teach students read effectively.

3. The lack of theoretically knowledge of EFL.Wallace (1992) explains that it can affect the situation where the teachers usually have little idea about how to plan a lesson regularly and systematically. Thus, what the teachers often do just sitting on the desk, going through the whole text to be taught, looking up in dictionarry all the words and expressions.

Based on the description above, it can be inferred that the teacher who get difficulty in teaching reading might not realize that affective factors also play a significant role in how reading helps one learn a language as stated by Brown (2001). This means that those who like what they read keep reading. In addition, Silver (1997 in Berardo, 2006) argues that there is a high correlation between those who read a lot and those who improve in their comprehension and vocabulary acquisition when they read. In other word,selecting and adapting materials is useful to make the process of teaching and learning effective. Thus, in order to make reading activity meaningful teacher should allow students to select their reading material. As stated by Atwell(1998) thatfree selection of reading material has a strong impact on learner's fluency, reading rate and comprehension

Based on the description above, Winter(2000) suggests that teachers need to provide the textsthat cover a range of genres and topics in order to increase students' motivation for reading.Furthermore, Nuttall (1996: 172) states that the wide variety of different types of text means that it is easier to find something that will interest the learner and may even encourage further reading or reading for pleasure.

Finally, in order to develop students' reading ability it can be done by encouraging students to read for pleasure. As stated by Green and Oxford (cited in Brown, 2001: 301) that reading for pleasure and reading without looking up all the unknown words were both highly correlated with overall language proficiency.

\section{Methodology}

This presents a brief discussion of methodology, including research design, the research site, research participants, data collection and analyses.

\section{a. Research Design}

Relevant to the purposes and the research questions previously mentioned, this study employed a qualitative approach which is regarded suitableto understand the process of teaching reading comprehension by which events and actions take place (Maxwell, 1996: 19). This study 
was conducted to observe and to record how things occur or what happens as things naturally occur in a natural setting (Fraenkel and Wallens, 2008).

Moreover,, since this study attempted to investigate teachers' techniques and problems in teaching reading, the data gained were analyzed in a descriptive way to explore their attitude, behavior and experience which emerged along teaching program (Dawson, 2009). As a result, the data focuses on process, and participants' item of view is essential. From this perspective, it can be inferred that the objective of qualitative research is to understand participants from their items of view (McMillan, 1992).

This study can also be regarded as a case study since it was conducted in a small scale, a single case, focus on one particular instance of educational practice (Nunan, 1992). Thus, it can maintain 'deeper' understanding of social phenomena that is teaching program (Silverman, $2005 ; 10)$.

\section{b. Research Site}

This study was carried out in one senior high school in Bandung Barat regency. The prior reason for choosing this site was the researcher's intention to investigate the teachers' techniques in teaching reading comprehension because the researcher has known that the English teacher in this school applied the techniques in teaching reading. Therefore, the result of the study would give valuable information about various techniques in teaching reading and can be useful in improving the quality of teaching and learning English. Another reason was the researcher has been involved in the English teaching in the research site for two years that it was expected to promote the feasibility of the study in gaining the data

\section{c. Research Participants}

The participant of the study were all English teachers in one senior high school in Bandung Barat regency. However, in order not to spend much time, funds and energy, the researcher used purposive sampling (Alwasilah, 2006: 72). Thus, two English teachers were selected as the participants of this study based on the researcher's personal judgment to select a sample (Fraenkel\&Wallen, 2008: 99). These teachers are purposefuly selected since they have been teaching English for more than fitften years. Therefore, these teachers are regarded as role model for another English teachers. By selecting these teachers, it is expected that the techniques in teaching reading used in the classcan be explored effectively.

\section{d. Data Collection}

The data in this study were obtained through observation and questionnaires.Each technique was elaborated in the following sections.

\section{1) Classroom observation}

In qualitative research, one of the primary data resourcesis observation (Silverman,2005).The classroom observation was used to investigate the teachers' techniques in teaching reading.In the classroom observation, the researcher played a role as non-participant observer. Thus, the researcher's involvement in the setting's central activities aimed to reveal depth information from the classroom activities (Creswell, 1994: 150).

The classroom observation was conducted to two classes during two sessions for each class. It was started from September 6 th - October 12th, 2015. Each observation lasted 90 minutes $(2$ x 45 minutes). The observation was carried out when the teachers were teaching reading. Therefore, the observation enabled the researcher to investigate the techniques used by the teachers in teaching reading comprehension.

During the observation, the writer used field note as the main instrument.It is used in order to observe what is going on or what is happening in the observed context(Fraenkel and Wallen, 2008). The researcher sat at the back of the classroom and took notes about about was happening during the teaching process. The researcher used fieldnotes because the students' attention was distracted when they were videotaped.

\section{2) Questionnaire}

Questionnaires are any written instruments that presents respondents with a series of questions or statements to which they are to react either by writing out their answers or by selecting from among existing answers (Brown, 2001: 6, cited from Dornei, 2003: 6).Questionnaire was used in this study to support observation data. Open-ended questionnaire was adopted to allow the respondents to answer in their own words (Brown, 2009: 202). 
The questionnaires were written in Bahasa Indonesia to ensure complete understanding of the items of by the participants. They were used to investigate teachers' techniques in teaching reading comprehension as well as examining teachers' problem in teaching reading.

\section{e. Data Analysis}

The data of this study were analyzed through qualitative data analysis. All data were analyzed based on research questions stated in chapter one. They were categorized into two main themes namely: teachers' techniques in teaching reading comprehension and teachers' problems in teaching reading.

The data from observation results were analyzed in several steps. First, all of the field notes were concerning teaching and learning process were transcribed. Second, the transcribed data were categorized based on the theme. Third, the categorized data were interpreted to answer the first question.

Data from questionnaire was analyzed bythe following steps. First, transcribing all the respondents' answers. Second, categorizing all the students' responses into aspects related to central themes of the study, in line with the research questions formulated in chapter one. Finally, interpreting the data by relating them to the theories as described in chapter two.

\section{RESEARCH FINDINGS AND DISCUSSIONS}

This chapter presents the research finding and discussion dealing with the data that had been obtained from observation and questionnaires. It deals with describing the teachers' techniques in teaching reading and their problems faced in teaching reading.

\section{Teachers' Techniques in Teaching Reading}

As the result of the observation, it was found that the activities in reading classes are divided into three teaching stages; pre-reading, while-reading, and post-reading (Hood et.al, 2005; Brown, 2001; Wallace, 1992; and Tierney, 1990). The observation also shows that the respondents applied the similar techniques in teaching reading. It was revealed that there were two common reading techniques which were implemented in the reading class: comprehension question and vocabulary instruction. It is in line with the statement of Li-Juan (2007) that comprehension question and vocabulary are the foundation of reading comprehension, especially for reading in EFL context.

In general, some techniques used in reading activities cover Question Answering Techniques and Question Technique (Edmondson, 2006), and some techniques which are adapted from Muskingum College-Center for Advancement and Learning (CAL) : Recitation and Review (CAL, 2008).

\section{a. Pre-Reading Stage}

Based on the data obtained, there were some techniques used by the teachers in pre-reading stage.In this stage Respondent\#1 and Respondent\#2 applied Previewing technique and Vocabulary Instruction Technique (Edmondson, 2006), and Pre-Reading Questions and Brainstorming Technique (Wallace, 1992).

\section{1) Pre-Reading Questions and Brainstorming Technique}

Brainstorming is one of the activities which can be done in the pre-reading stages. This technique was applied in order to build students' background knowledge (Wallace, 1992). This technique can be done by using some pre-reading questions.

It can be seen from the example below taken from the teacher and students interaction in teaching reading at the pre-reading stage (R2, Observation \#2, September, $26^{\text {th }}$, 2015).

R\#2 : please take a look at the slide. What do you think about abortion? Do you agree or not?

Ss : no

R\#2 : according to your opinion, is there any people who agree with abortion?

Ss : yes, if the baby can influence the condition of his/her mother.

R\#3 : the topic like that belongs to discussion text. And now, we are going to discuss about discussion text.

The technique used for pre-reading by giving such pre-reading questions is called "Activation of Prior Knowledge" (Closs, 2006). During brainstorming activity, findings from the observation showed that by giving such pre-reading questions can make up 
great amount a process of reading comprehension and help the students to apply prior knowledge. It is in accordance with the statement of Closs (2006) that the activating prior knowledge is important because it can arouse the students' prior knowledge and experience. Therefore, it can be infered that this activity is regarded as the guidance before reading (Nuttall1996: 152) in order to activate students' prior and background knowledge to focus their attention on what they are going to learn.

\section{2) Previewing Technique}

The observation showed that the respondents asked the students to mention the title of the text first before they read the content of the text and asked them to make prediction about the text. The example of this technique can be seen from the following extract(R1, Observation \#1, September, $\left.16^{\text {th }}, 2015\right)$.

R\#1 : what is the text about?

Ss : it is about chocolate?

R\#1 : what is the color of the chocolate?

Ss : the color is chocolate.

R\#1 : chocolate is not the name of color. Cokelat in English is Brown.

It can be shown from the observation that the students were actively get involved in the activity and they could express their own prediction and expectation toward the text by answering the questions given to them. Therefore, previewing text is a beneficial preparation activity which enables students to establish their own expectations about what information they will find in the text and the way that information will be organized (Wallace, 2001).

\section{3) Discussing Text Types}

One of the activities in pre-reading stage is text types discussions (Barnet, 1988).The example of this technique can be seen from the following extrac $t\left(R 1\right.$, Observation \#1, September, $\left.16^{\text {th }}, 2015\right)$

R\#1 : do you know what is explanation text?

Ss : no....

R\#1 : it comes from the word explain and tion?

Ss : menjelaskan

R\#1 : no but penjelasan. So explanation text is about how the phenomena happen.

The result of the observation, it is revealed that after the teacher explained the text typeps the students can conclude the function of the text. As stated by Wallace (1992) that discussing the text type in teaching reading is intended to familiarize students with the text structure and to show how these language features can help them to work out the main function of the text. Thus, this technique is very useful for students as an aid to comprehend the text since reader understanding of how the texts are organized influences reading comprehension (Anderson, 1990).

\section{4) Vocabulary Instruction Technique}

In the pre- reading stage, all teachers gave some of vocabulary lists. It is in line with the suggestion of Gipe (1979 cited in Mickulecky, 1990) that this activity is very useful to help the students to memorize the words paired with a short definition or a synonym. The example below shows the questions of vocabulary instruction(R1, Observation \#1, September, $16^{\text {th }}, 2015$ ).

Match each word or phrase with its synonym or definition and find out the meanings of the words in Bahasa Indonesia.

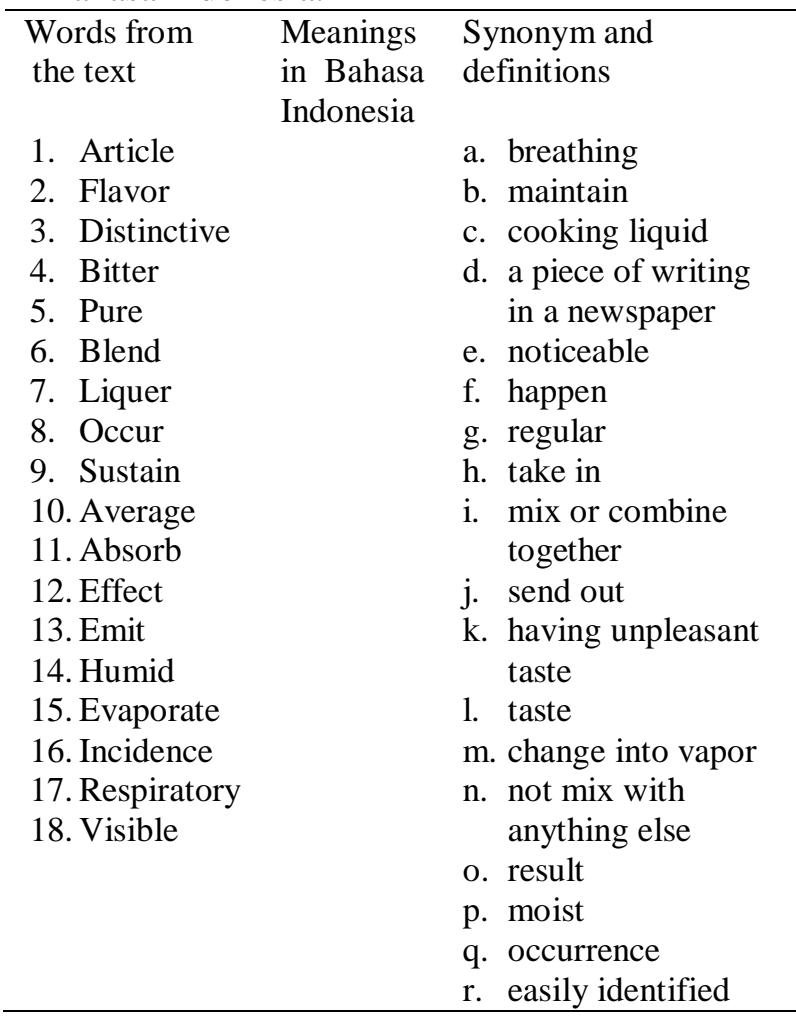

The observation also showed that the students did not get difficulty in comprehending the entire reading passage since they have known some of unfamiliar words in the beginning of reading activity.It showed that new vocabulary words should be taught prior to reading in order to help students to comprehend the text. As suggested by Closs (2006) that providing new vocabulary words 
can avoid the situation in which the students will spend too much time figuring out the new words that will be unable to comprehend the entire reading text.

From the data above, it can be concluded that a reading lesson should begin with a pre-reading activity to introduce the topic and to make sure students have enough vocabulary and background information to understand the text.

\section{b. While-Reading Stage}

During this stage, there were some techniques used by the respondents in teaching reading comprehension namely: Question-Answering Techniques and Question-Generating Technique (Edmonson, 2006), Vocabulary Instruction Technique (Closs, 2006), Recitation (CAL, 2008) and reading aloud.

\section{1) Question-Answering Technique}

The activity used in this technique is by giving the students comprehension questions. The example of comprehension questions are presented below:

The teacher asked the students to read the text silently and answer several comprehension questions as follows:

R\#1 Give the questions in the form of multiple choice as follows:

a) The text is about........
a. The cocoa tree
b. The cocoa beans
c. The raw chocolate
d. The making of chocolate
e. The flavor of chocolate

b) The third paragraph focuses on...
a. The process of producing chocolate
b. How to produce the cocoa flavor
c. Where chocolate comes from
d. The chocolate liquor
e. The cocoa fruit

c) "...,so they are often sorted and blended...."

The underlined word is close in meaning to.....
a. Arranged
b. Combined
c. Separated
d. Distributed
e. Organized

d) How does the chocolate maker start to make chocolate?
a. By fermenting the beans
b. By roasting the beans
c. By blending the beans

d. d. by sorting the beans

e. e. by drying the beans

While, the example below shows the comprehension questions ogiven by R\#2( Observation \#3, October, $\left.5^{\text {th }}, 2015\right)$. The questions are in the form of open questions.

Comprehension questions

a. What does tsunami mean?

b. From which language the term is taken?

c. What is a tssunami?

d. What can generate a tsunami?

e. Where can a large vertical movements of the earth's crust occur?

f. What is particularly effective in generating tsunami?

g. Where can it happen?

h. What happens when the displaced water mass moves under the influence of gravity to regain its equilibrium?

i. What does tsunami always bring?

j. What causes most of the damage? Why?

It is shown from the data above that all the questions given are in the form of explicit questions (Wallace, 2011). Explicit questions refer to the questions which involve students to find the information available in the text.It means that the students are required to find the answer from the information provided in the text.

\section{2) Vocabulary InstructionTechnique}

This technique involves vocabulary exercise such as matching words, cloze passage, and referring questions. R\#1 applied vocabulary instruction technique by giving cloze passage as can be seen in the following exercise.

Vocabulary Exercise

Complete the following passage with the words listed on the box!

Liquid Fermented sorted bitter Grow

flavor seed ground winnowed produces

Have you ever wondered how people get chocolate for? In this article we'll enter the amazing world for chocolate so you can understand exactly what you're eating. Chocolate starts with a tree called the cacao tree. This tree..........(1)...... in equatorial region, especially in place such as South America, Africa and Indonesia. The cacao tree.......(2)......... fruit about the size of small pine apple. Inside the 
fruit are the tree's (3)..... also known as cacao beans.

The beans are.........(4).........about a week dried in the sun then shipped to the chocolate maker. The chocolate maker starts by roasting the beans to bring out the.......(5).......Different beans from different place have different qualities and flavor, so they are often.......(6)....... and blended to produce a distinctive mix. Next, the roasted beans are .........(7)........ winnowing removes the meat nib of the cacao bean from its shell. Then, the nibs are blended. The blended nibs are .......(8)........ to make it liquid. The liquid is called chocoalate liquor. It taste.........(9)......... All seed contain some amount of fat, and cacao beans are not different. However, cacao beans are half fat, which is why the ground nibs from ........(10)........ it's pure bitter chocolate.

\section{3) Recitation Technique}

The respondents applied Recitation technique by asking the students to recite the story related to the text. Retelling is one of the activity in whilereading stage.The example of this technique can be seen from the following extract(R2, Observation \#2, September,26 ${ }^{\text {th }}, 2015$ )

$\mathrm{R} \# 2$ : what does the first paragraph mainly tell us about?

Ss : it is about the effect of TV for children

R\#2 : How about the second paragraph?

Ss : TV can give the information.

R\#2 : and then what else?

Ss : education and entertainment

In addition, the findings also showed that $\mathrm{R \# 2}$ asked the students comprehension questions and clarified the answer to the class in order to make sure that they understand the text. It is in line with Anderson's (1999) statement that justifying comprehension is a technique that ask the students to read a passage, then ask comprehension question, and then ask the class to justify the answer.

The result of observation showed that the respondents asked the students to retell the reading passage given to them. It can be seen that through the activity the teacher could assess the students' understanding toward the text. It is in line with the statement of CAL (2008) that the recitation is effective because it enables the students to recall the important points from the text.

\section{4) Reading Aloud Technique}

The example of this strategy can be seen from the following extract $\left(\mathrm{R} 1\right.$, Observation $\# 3$, October, $6^{\text {th }}$, 2015).

R\#1 : Ok students now I am going to read the text and please listen to me carefully.

Ss : (Listen to the teacher)

R\#1 : have you found difficult words in the text?

Ss : absorb

R\#1 : ok what does absorb mean? Is there anyone who knows its mean?

Ss : I don't know.

R\#1 : absorb means menyerap.

The result of data observation showed that the interaction between the teacher and students can help students to comprehend the text better. Therefore, this activity plays an important role to develop reading competence.

\section{c. Post Reading Stage}

In this stage, the respondents used the following strategies in teaching reading comprehension reviewing (CAL, 2001) and follow up technique.

\section{1) Reviewing Technique}

In general, all the respondents in this study applied reviewing technique by asking the students to ask the students to conclude the lesson they have learned. They reviewed generic structure each text that has been discussed.

The example below shows the activity of reviewing in the classroom(R\#2, Observation \#2, September, $26^{\text {th }}, 2015$ )

R\#2: so we can conclude that the generic structures of the text are .....

Ss : Issue, supporting ideas, contrasting idea and recommendation and conclusion.

R\#2 : ok. Good. Then, what is the social function of the text?

Ss : to present a problem/ issue from at least from two different points of view until it reaches a conclusion and recommendation.

The observation showed that through this activity the students' understanding can be assessed. As stated by CAL (2006) that through reviewing activity, the teacher can also see how the information fits together in the students' understanding. 
Therefore, it can be inferred that reviewing is considered need to be applied in order to reflect what has been learned and to relate the text to the students' knowledge, interests or views (Wallace, 2001; Closs, 2006; Edmondson 2006).This means that the main goal of the post-reading stage is to further develop and clarify interpretations of the text, and to help students remember what they have individually created in their minds from the text.

\section{2) Following up Technique}

The respondents\#1 applied follow up activity technique by giving the students homework as the last activity during reading class. Based on the observation, it can be seen that the respondent \#1 asked the students to the text. It is in line with the suggestion of Edmundson (2006) that the teacher needs to ask the students to do the summarizing activity.It means that students' writing skill can be improved through doing follow up activity. Therefore, follow-up activity is the effective strategy to transfer reading skill to the texts and to integrate reading skill to other language skill (Wallace, 1992; Barnet 1988).

This finding is in line with questionnaire data, R\#1 pointed out that the teacher usually gives the students homework such as matching the word with its definition, completing the sentences and translating the text.In short, the main point of using post reading activities is variety, which leads to creating positive, creative, innovative, effective and fun activities.

\section{Teachers' Problems in Teaching Reading}

Dealing with teaching reading, the respondents faced various difficulties as it is revealed from classroom observation and the questionnaire. From the result of observation and questionnaire revealed that the teachers' problems in teaching reading are mostly similar.

From the findings of classroom observation conducted, it was revealed that the problems encountered by the respondents are generally similar. The first problem dealt with lack of students' vocabulary mastery that makes students spend too much time figuring out the new words that will be unable to comprehend the entire reading text. This is in accordance withNunan's (1991) statement that vocabularies are used as vehicle of the language to communicate.
Consequently, by having many stocks of words, the learners can comprehend the passage easily.

Second, it was revealed from observation that some students reluctant to engage in reading activities with any enthusiasm. This unwillingness may derive from lack of motivation. This is in line with the data of questionnaire that R\#1 and R\#2 pointed that lack of students' motivation as the problems in teaching reading. Therefore, teachers need to provide the textsthat cover a range of genres and topics in order to increase students' motivation for reading (Winter, 2000). Furthermore, Nuttall (1996: 172) states that the wide variety of different types of text means that it is easier to find something that will interest the learner and may even encourage further reading or reading for pleasure.

Third, it was revealed from the questionnaires that R\#2 pointed out that the students were not used to read a lot on a regular basis. In order to cope with this problem, the students should be encouraged to read continuously on any topic of their choice. As stated by Atwell(1998) thatfree selection of reading material has a strong impact on learner's fluency, reading rate and comprehension

Finally, R\#2 pointed out there are too many reading material that should be taught to the students. Consequently, the teacher could not finish all the material in one semester. It is supported by R\#1 who pointed time allocation as the problem in teaching reading.

\section{CONCLUSIONS}

Teacher's technique in teaching reading is regarded as one of the fundamental factors since they can promote students' comprehension in reading. Accordingly, this study explored teachers' techniques in teaching reading. It also examines the problems that the teachers encountered in teaching reading. Based on findings and discussion as discussed in Chapter Five, several conclusions from the findings are drawn as follows.

Firstly, regarding the teachers' techniques in teaching reading, it was found that the activities in reading classes are divided into three teaching stages; pre-reading, while-reading, and postreading (Hood et.al, 2005; Brown, 2001; Wallace, 1992; and Tierney, 1990).

The observation also shows that in pre-reading stage the respondents applied Previewing 
technique and Vocabulary Instruction Technique (Edmondson, 2006), and Pre-Reading Questions and Brainstorming Technique (Wallace, 1992) and discussing text type. The result of classroom observation also revealed that by applying those techniques in pre-reading stage, the students can easily comprehend the entire reading text without spending too much time figuring out the new words (Closs, 2006) since thethey have known some of unfamiliar words in the beginning of reading activity. In addition, previewing text is a beneficial preparation activity which enables students to establish their own expectations about what information they will find in the text and the way that information will be organized (Wallace, 2001). The last, reader understanding of how the texts are organized influences reading comprehension (Anderson, 1990).

Therefore, it can be infered that the techniques in pre reading stage is important to be applied in reading class. It is regarded as the guidance before reading (Nuttall1996: 152) to activate students' prior and background knowledge to focus their attention on what they are going to learn.

While, during while reading stage, the result of the observation showed that there were some techniques used by the respondents in teaching reading comprehension namely: QuestionAnswering Techniques (Edmonson, 2006), Vocabulary Instruction Technique (Closs, 2006), Recitation and Reading aloud. In this stage, all the respondents focuses on the developments of the students' reading skills. It is in accordance with Wallace(1992) that the aim of while reading stage is to help students understand writer's purpose and text structure to clarify the content of the text.

Furthermore, in post reading stage, all respondents used reviewing technique and follow up strategy. In this stage, the students need to reflect what has been learned and to relate the text to the students' knowledge, interests or views as suggested by Wallace (2001); Closs (2006); and Edmondson (2006). This means that the main goal of the postreading stage is to further develop and clarify interpretations of the text, and to help students remember what they have individually created in their minds from the text.

The last, the result concerning the problem encountered by teachers in reading class is generally similar. It was revealed that there were four problems encountered by the respondents in teaching reading: lack of students' vocabulary mastery, lack of motivation in reading, students were not used to read a lot on a regular basis and teaching time allocation.

Based on the conclusions above, some recommendations are suggested to the teachers, students, and other researchers. Regarding the result of the research, it is recommended for English teachers to select appropriate technique in teaching reading which are relevant to the students' needs. In addition, In addition, the teachers also are expected to improve their ability in teaching practice. It can be done through joining some trainings and workshops about techniques in teaching, reading a lot of sources, and sharing information with others teachers.

Moreover, teachers also need to provide the texts that cover a range of genres and topics in order to increase students' motivation for reading (Winter, 2000). Furthermore, Nuttall (1996: 172) states that the wide variety of different types of text means that it is easier to find something that will interest the learner and may even encourage further reading or reading for pleasure.

Furthermore, concerning the benefits that the students obtained from reading, it is better for the students to get into the habit of writing regularly. In this case, they should be encouraged to read continuously on any topic of their choice.As stated by Atwell(1998) thatfree selection of reading material has a strong impact on learner's fluency, reading rate and comprehension

Finally, as this research only concerns on teachers' techniques in teaching reading at senior high school, the further research should be conducted for higher levels.

\section{E. BIBLIOGRAPHY}

Alderson, J. Charles. 2000. Assessing Reading. New York: Cambridge University Press.

Anderson, N. (1991). Individual Differences in Strategy Use in Second Language Reading and Testing. Modern Language Journal, 75, 460-472.

Amanda, R. Aska. (2007). Reading Strategies Used by Second Grade Students of Junior HighSchool. Unpublished Undergraduate Thesis, Department of English Education: Indonesia University of Education. 
Alwasilah. A. C. (2006). Pokoknya Kualitatif. Dasar-Dasar Merancang dan Melakukan Penelitian Kualitatif. Jakarta: Pustaka Jaya.

Barnet, M.A. (1988). Teaching Reading in a Foreign Language. Retrieved September, $10^{\text {th }}$, 2015 from http://www.erictdigests.org/pre-9211/readi ng.htm.

Berardo, S. Anthony. (2006). The Use of Authentic Materials in the Teaching of Reading:LinkSuccess. The Reading matrix, 6 (2).Retrieved September, $10^{\text {th }}$, 2015 from http://www.readingmatrix.com /articles/berardo/article.pdf.

Brown, H.D. (2001). Teaching by Principles: An Interactive Approach to

Language Teaching. White Plains, NY: Addison Wesley Longman.

Brown, J. D. (2009). "Open-Response Items in Questionnaires". In Heigham, J. \&

Crocker, R. A. (Eds.). Qualitative Research in Applied Linguistics.New York: Palgrave Macmillan.

Carrell, P. L. \& Eisterhold, J. C. (1988). Schema Theory and ESL Reading Pedagogy. In Carrell, P. L., Devine, J. \& Eskey, D. (eds.) Interactive Approaches to Second Language Reading. Cambridge: Cambridge University Press. 73-89.

Closs, Ellen, K. (2006). Teaching Reading Comprehension to Struggling Readers: Strategies That Work. Available [on line] at http://www.readinglady.com/mosaic/ tools/TeachingReadingComprehensionStru gglingReaders-MastersThesisbyEllen.pdf. (Accessed on 16st August, 2015)

Cook, Vivian. (1991). Second Language Learning and Language Teaching. London: Edward Arnold.

Crawford, A., Saul, E.W., Mathews, S. And Makinstner, J. (2005). Teaching and Learning Strategies for Thinking Classroom. New York: The International Debate Education Association.

Cresswell, J. W. (1994). Research Design: Qualitative \& Quantitative Approaches. USA: Sage Publications, Inc.

Dawson, C. (2009). Introduction to Research Methods.Oxford: How to Books.

Depdiknas. 2006. PeraturanMendiknasNomor 23/ 2006 Tentang SKL Untuk Satuan PendidikanDasardanMenengah.Jakarta:De partemenPendidikanNasional.
Dorney, Z. (2003). Questionnaires in Second Language Research. New Jersey: Lawrence Erlbaunm Associates, Inc.

Durkin, D. (1993). Teaching Them to Read (6th Ed.). Needham, MA: Allyn and Bacon.

Edmondson, Patricia. (2006). Scaffolding: Strategies for Improving Reading Comprehension Skills. Available [online] at http://www.phschool.com/eteach/langu agearts/2006 12/essay.html-12k/ (Accessed on 16st August, 2015)

Frankel, J. R. \& Wallen, N. E. (2008). How to Design and EvaluateResearch in Education 7th edition.New York: McGraw-Hill.

Gebhard, J.G. (1999). Teaching English as a Foreign or Second Language. Ann Arbor: The University of Michigan Press

Glendinning, Eric H, and Holmstrom, B. (1992). Study Reading:A Course in Reading Skill for Academic Purposes. Cambridge: Cambridge University Press.

Grabe, W. \&Stoller, F. L. (1990).Teaching and Researching Reading. Malaysia: Pearson Education Limited.

Gunning, T. G. (2010).Reading Comprehension Boosters. USA: Jossey-Bass.

Harris, T. L., \& Hodges, R. E. (1995). The Literacy Dictionary: TheVocabulary of Reading and Writing. Newark, DE: International Reading Association.

Harris, R. A. \&Sipay, E. R. (1980).How to increase Reading Ability. NY: David Mckay.

Harmer, J. (2007).How to Teach English. Essex, UK: Pearson-Longman.

Lems, K, Miller. L.D,\&Soro T.M. (2010). Teaching Reading to English Language

Learners: Insights from Linguistics. New York: The Guilford Press.

Li-Juan, Jiao. (2007). Problems in EFL Reading Teaching and Possible Solutions.

Dallan, China: School of Foreign Language Dallan Polytechnic University.

Marzban, Amir. (2013).Effects of Implicit Versus Explicit Vocabulary Instruction on Intermediate EFL Learners' Vocabulary Knowledge. - India International Journal ISSN2230-9136 (Print) 23217170.Retrived October $5^{\text {th }}, 2015$ from http: //eltvoices.in/Volume3/Issue_6/EVI_36_1 1.pdf.

Maxwell, J. A. (1996). Qualitative Data Analysis: A Source Book of New Methods.London: Beverly Hills. 
McMillan, J. H. (1992). Educational Research: Fundamentals for the Consumer. New York: Harper Collins Publishers, Inc.

McNeil, J. D. (1992). Reading Comprehension New Directions for Classroom Practice $\left(3^{r d} e d\right.$.). Los Angeles, CA: University of California.

Mikulecky, B.S. (1990). A Short Course in Teaching Reading Skill. USA: Addison Wesley Publishing Company.

Mohammad, A. (1999). What do We Test When Test Reading Comprehension?Available online http://iteslj.org/techniques/moham madtestingReading-html.

Mulyani, M and Siswayani, P. (2006). Meaningful English for Academic Purpose (EAP) Learning with Student's Preferred Text Types and Reading Activities. Presentation in $57^{\text {th }}$ TEFLIN the International Conference: Indonesia University of Education. Muskingum College Center for Advancement and Learning (CAL). Reading Comprehension. Available online http://www.muskingum.edu/cal/database/g eneral/reading.html-248k.

Nashriyah.(2010). A Study of Indonesian Students' Reading Strategies. IIEF, Jakarta: Embassy of United States.

The Grantees and Partners of RELO. (2010). Selected Papers in English Language Teaching.

Nunan, D. (1991). Language Teaching Methodology: a Text Book for Teachers. London: Prentice Hall International (UK) Ltd.

Nunan, D. (1992). Research Methods in Language Learning. New York: Cambridge University Press

Nunan, D. (1999). Second Language Teaching and Learning. Boston: Heinle and Heinle Publisher.

Nuttal, C. (1996).Reading Skills in a foreign Language. Oxford: Heineman.

Razi, Salim. (2001). The Effects of Cultural Schema and Reading Activities on Reading Comprehension. [online]. Available: $\mathrm{http}: / / \mathrm{www} \cdot$.readingmatrix.com/conference/ $\mathrm{pp} /$ proceedings/razi.pdf.

Silverman, D. (2005). Doing Qualitative Research. London: SAGE Publication Ltd.

Surong, Jing. (2002). A Strategy-Oriented Teaching Model of EFL Reading. [online]. Available: http://www.celea.org.cn/past version/lw/pdf/jingsurong.pdf.
Sweet, P.A \& Snow, C.E (Ed). (2003). Rethinking Reading Comprehension. New York: The Guilford Press.

Syatriana, E. (2010). Developing a Model of Teaching Reading Comprehension of EFL Students. TEFLIN Journal, Vol.21.1: 27-40

Tercanlioglu, Leyla. (2004). Postgraduate Students' Use of Reading Strategies in L1 and ESLContexts: Link to Success. International Education Journal, 5 (4). Retrived November $5^{\text {th }}, 2010$ from http://www.iej.cje.ne.

Wallace, C. (1992). Reading. Oxford University Press.

Wallace, C. (2001).Critical Reading in Language Education. MacMillan: Palgrave

Winter, G. (2000).Independent Reading Logs. Retrieved August, 18 ${ }^{\text {th }}, 2015$ From Available: http://faculty.necc.mass.edu/ reading/independentrdglog.htm.

Zamel, V. (1982). 'Writing: The Process of Discovering Meaning'. TESOLQuarterly, 16 (2), pp. 195- 209. 